\title{
Association of copy number variation in Fc gamma receptor IIIb gene with risk of Graves' ophthalmopathy
}

\author{
Wen-Ling Liao ${ }^{a}$, Yu-Huei Liu ${ }^{\mathrm{b}, \mathrm{c}}$, Lei Wan ${ }^{\mathrm{c}, \mathrm{d}, \mathrm{e}}$, Chwen-Tzuei Chang ${ }^{\mathrm{f}, \mathrm{g}}$, Ching-Chu Chen ${ }^{\mathrm{f}, \mathrm{g}}$, \\ Yung-Hsiang Chen ${ }^{\mathrm{c}}$, Fuu-Jen Tsai ${ }^{\mathrm{b}, \mathrm{d}, \mathrm{e}, \mathrm{h}, *}$ \\ a Centre for Personalized Medicine, China Medical University Hospital, Taichung, Taiwan \\ b Department of Medical Research and Medical Genetics, China Medical University Hospital, Taichung, \\ Taiwan \\ c Graduate Institute of Integrated Medicine, China Medical University, Taichung, Taiwan \\ d School of Chinese Medicine, China Medical University, Taichung, Taiwan \\ e Department of Health and Nutrition Biotechnology, Asia University, Taichung, Taiwan \\ f Division of Endocrinology and Metabolism, Department of Medicine, China Medical University Hospital, \\ Taichung, Taiwan \\ g Department of Endocrinology and Metabolism, College of Chinese Medicine, China Medical University, \\ Taichung, Taiwan \\ h Department of Pediatrics, China Medical University Hospital, Taichung, Taiwan
}

*Corresponding author, e-mail: d0704@www.cmuh.org.tw

Received 20 Mar 2012

Accepted 9 Aug 2012

\begin{abstract}
The functional polymorphism that explains the established association of $F c$ gamma receptor IIIb $(F C G R 3 B)$ with Graves' disease (GD) and Graves' ophthalmopathy (GO) remains unidentified, but copy number variation (CNV) might be relevant. The aim of this study was to determine whether CNV for FCGR3B is associated with GD and GO. Genotype analysis involved $624 \mathrm{GD}$ patients, including 397 without $\mathrm{GO}\left(\mathrm{GD}_{\text {nonGO }}\right)$ and 227 with $\mathrm{GO}\left(\mathrm{GD}_{\mathrm{GO}}\right)$, and 227 healthy controls. The relative copy number $(\mathrm{CN})$ of $F C G R 3 B$ was determined using a relative real-time quantitative polymerase chain reaction. Our findings indicated the distribution of the relative $\mathrm{CN}$ of $F C G R 3 B$ significantly differed between the $\mathrm{GD}_{\mathrm{GO}}$ patients and the healthy controls $(p=0.02)$ but not between the total GD patients and the healthy control groups $(p=0.06)$. Individuals with less than $2 \mathrm{CN}$ or more than $2 \mathrm{CN}$ of $F C G R 3 B$ were at significantly decreased risk of developing $\mathrm{GD}_{\mathrm{GO}}$. In addition, GD patients with less than 2 copies of $F C G R 3 B$ were at reduced risk for developing nodular hyperplasia and vitiligo, but at increased risk for myxedema. Our results suggest that $\mathrm{CNV}$ of $F C G R 3 B$ is associated with the development or progression of GD in Taiwan Chinese population.
\end{abstract}

KEYWORDS: thyroid eye disease, autoimmune disease, goitre, exophthalmos

\section{INTRODUCTION}

Graves' disease (GD) is an autoimmune disease characterized by hyperthyroidism, diffuse goitre, thyroidspecific autoantibodies with or without Graves' ophthalmopathy (GO), and dermopathy due to the circulating autoantibodies ${ }^{1}$. GO is the most common extrathyroid manifestation of GD and affects $25 \%$ $50 \%$ of GD patients ${ }^{2-5}$. Approximately $28 \%$ of patients with GO present with severe disease, with restricted mobility, diplopia, keratopathy, and optic neuropathy ${ }^{6,7}$. Numerous functionally relevant singlenucleotide polymorphism (SNP) variants have been characterized in GD and GO, although none have yet proven causative ${ }^{8}$. Other forms of variation that might affect gene expression should also be considered.
Copy number variation (CNV) is recognized as a common form of genomic variation in which DNA segments $(>1 \mathrm{~kb})$ are present in a variable number of copies compared to a reference genome. A CNV caused by genomic rearrangements such as deletions, duplications, inversions, and translocations may contribute to alteration of gene expression and subsequent phenotypic variation, which results in susceptibility or resistance to disease ${ }^{9-11}$. CNV has also been associated with autism ${ }^{12-15}$, schizophrenia ${ }^{16-19}$, cancer $^{20-25}$, and autoimmune disease ${ }^{11,26-30}$.

Fc gamma receptor IIIb (FCGR3B), the CD16 cell surface immunoglobulin receptor, located on chromosome 1q23, is a low-affinity $\mathrm{IgG}$ receptor that binds with $\operatorname{IgG}$ complexes at the $\mathrm{Fc}$ region ${ }^{31}$. $F C G R 3 B$ belongs to the Fc gamma receptor fam- 
Table 1 Demographic and clinical characteristics of 624 patients with Graves' disease.

\begin{tabular}{lr}
\hline Mean age at diagnosis (S.D.), yrs & $41.1(12.9)$ \\
Gender & \\
Male & $132(21.2 \%)$ \\
Female & $490(78.5 \%)$ \\
Clinical features & \\
Ophthalmopathy & $227(36.4 \%)$ \\
Goitre & \\
Grade 2 \& 3 & $474(76.4 \%)$ \\
Grade 0-1b & $147(23.6 \%)$ \\
Nodular hyperplasia & $574(92.0 \%)$ \\
Myxoedema & $114(18.3 \%)$ \\
Vitiligo & $98(15.7 \%)$ \\
\hline
\end{tabular}

Abbreviations: S.D., standard deviation; yrs, years

ily, which contributes to the regulation of acquired and innate immunity ${ }^{31}$. Studies have shown that a lower copy number of $F C G R 3 B$ can increase the susceptibility to systemic autoimmune diseases such as systemic lupus erythematosus and other autoimmune disorders ${ }^{27}$. Although there have been major advances in understanding the genetic basis of $\mathrm{GD}^{27}$, the association between the variation of copy number in $F C G R 3 B$ gene and the risk of GO remains unclear. In the present study, the variant in the $F C G R 3 B$ gene that may explain the association between, and the physiological impact of, CNV in this region and the development of GD and GO was found.

\section{MATERIALS AND METHODS}

\section{Subjects}

A disease group with 624 patients with a confirmed diagnosis of GD and an appropriate control group with 227 healthy volunteers with matched gender according to the female predominance of GD including 32 male $(20.0 \%)$ and 128 female $(80.0 \%)$ at China Medical University Hospital in Taiwan were enrolled and actively followed. The methods of diagnosis of GD and classification of GO were as previously described $^{32}$. All individuals classified as affected were interviewed and examined by experienced clinicians. Demographic and clinical characteristics of 624 patients with GD are summarized in Table 1 . The study was approved by the institutional review board and the ethics committee of China Medical University Hospital (DMR96-IRB-109; approved 2007 September). Written informed consent was obtained from each participants in accordance with institutional requirements and the Declaration of Helsinki Principles.

\section{Genomic DNA extraction}

The genomic DNA was extracted from peripheral blood leukocytes of participants using the Genomic DNA kit (Qiagen) according to the manufacturer's instructions. Considering that the quantitative polymerase chain reaction (qPCR) technique is sensitive to small variations in DNA quality ${ }^{33}$, the quality of each genomic DNA was verified on an agarose gel and the template DNA were freshly diluted from $200 \mu \mathrm{g} / \mathrm{ml}$ stock and used within 2 weeks.

\section{Analysis of FCGR3B copy number variants}

The relative $\mathrm{CN}$ of the $F C G R 3 B$ gene in each individual was estimated using a relative real-time qPCR method that is suited to larger-scale genotyping. This method has been tested and proven to provide reliable results. Specific TaqMan probes (Assay ID: Hs04211858_cn) for FCGR3B and for a reference gene RNase $P$ (RNaseP part number 4403326) were purchased from ABI Biosciences (Applied Biosystems, Foster City, CA, USA). The TaqMan probes for FCGR3B and RNase $P$ were labelled with FAM and VIC, respectively. Polymerase chain reactions were run on an ABI 9700 machine. Amplification reactions $(15 \mu \mathrm{l})$ were carried out using genomic DNA (10 ng), TaqMan Copy Number Reference Assay for FCGR3B and RNase P, and TaqMan Master Mix. Thermal cycling was initiated with an initial denaturation step of $10 \mathrm{~min}$ at $95^{\circ} \mathrm{C}$, followed by 40 cycles each of $15 \mathrm{~s}$ at $95^{\circ} \mathrm{C}$ and of $1 \mathrm{~min}$ at $60^{\circ} \mathrm{C}$. A dissociation procedure was performed to generate a melting curve to confirm amplification specificity. The relative $F C G R 3 B \mathrm{CN}$ for each individual was estimated using the $2^{-\Delta \Delta \mathrm{Ct}}$ method, where $\mathrm{Ct}$ is cycle threshold, $-\Delta \mathrm{Ct}=\left(\mathrm{Ct}_{\text {gene }}-\mathrm{Ct}_{\text {reference }}\right)$ as described previously ${ }^{34}$. The PCR products were quantified in triplicate, and the standard deviation and coefficient of variation (CV) were calculated based on 3 runs. To control for reaction quality, each reaction plate also included a calibrator, a positive control, and a no-template control (NTC). Data from a plate were included if the calibrator $\mathrm{CV}$ was less than $5 \%$, the positive control $\mathrm{CV}$ and sample $\mathrm{CV}$ s were all less than $10 \%$, and the NTC was negative. To include acrossplate data, the CVs of the positive control had to be similar and the NTC had to be negative.

\section{Statistical analysis}

Significance of the differences between the distributions of $F C G R 3 B \mathrm{CN}$ in cases and controls was estimated by Chi square test or Fisher's exact test. Odds ratios (OR) and confidence intervals (CI) were 
estimated by logistic regression models using SPSS 12.0. The $\mathrm{CN}$ equal to two $(\mathrm{CN}=2)$ was chosen as reference category for $F C G R 3 B$. To estimate OR, bins of $\mathrm{CN}$ were grouped as $0-1 \mathrm{CNs}$ for $F C G R 3 B(<2$ category), 3-5 CN for $F C G R 3 B$ (> 2 category). We estimated the risk of acquiring disease associated with CNs for $F C G R 3 B$ categories by comparing them with a reference $\mathrm{CN}$ category. For each of these categories, an $\mathrm{OR}>1$ indicates a detrimental effect of $\mathrm{CNV}$ on disease susceptibility, and $\mathrm{OR}<1$ indicates a protective effect of $\mathrm{CNV}$.

\section{RESULTS}

\section{Correlation between CNV of FCGR3B and the development of GD and GO}

The distribution of FCGR3B copy number $(\mathrm{CN})$ according to the presence of GD or GO is summarized in Table 2. The distribution of $F C G R 3 B \mathrm{CN}$ was not statistically significant different between health controls and GD $(p=0.06)$. Further, we separated GD patients into 2 groups according to GO status. The distribution of FCGR3B CN was significantly different between healthy control and $\mathrm{GD}_{\mathrm{GO}}$ patients $(p=0.0176)$ but not with $\mathrm{GD}_{\text {nonGo }}$ patients $(p=0.14)$. Our results revealed that individuals with $F C G R 3 B$ copy number not equal to 2 were at significantly decreased risk of developing $\mathrm{GD}_{\mathrm{GO}}$ when compared to individuals with 2 copies of $F C G R 3 B$ (odds ratio $(\mathrm{OR})=0.45,95 \%$ confidence interval (C.I.): $0.24,0.84$ and $\mathrm{OR}=0.66$, 95\% C.I.: $0.42,1.06$ for $\mathrm{CN}<2$ and $\mathrm{CN}>2$, respectively) (Table 2). The result (control versus $\mathrm{GD}_{\mathrm{GO}}$ patients) was statistical significant after Bonfferoni correction $(p=0.035)$. Regression analysis with or without gender and age as covariates did not affect the significance of the reported association results. The results suggest that $F C G R 3 B \mathrm{CNV}$ might not be associated with the development or progression of GD, but could be associated with the development or progression of $\mathrm{GD}_{\mathrm{GO}}$.

\section{Correlations between CNVs of FCGR3B and clinical phenotypes}

The association between clinical features of GD patients and $\mathrm{CNV}$ of $F C G R 3 B$ was analysed. The results are summarized in Table 3. No significant difference for FCGR3B CNV was found between GD patients and different stages of goitre $(p=0.47)$. Interestingly, the distribution of $F C G R 3 B \mathrm{CNV}$ significantly differed between GD patients with different patterns of nodular hyperplasia $(p=0.02)$, myxoedema $(p=$ $0.04)$, and vitiligo $(p=0.02)$. As shown in Table 3 , individuals with less than 2 copies of $F C G R 3 B$ were
Table 2 The distribution of $F C G R 3 B$ copy number in normal, and Graves' disease with or without ophthalmopathy.

\begin{tabular}{cccccc}
\hline $\mathrm{CN}$ & Normal & $\mathrm{GD}_{\text {total }}$ & $\mathrm{GD}_{\text {nonGO }}$ & $\mathrm{GD}_{\mathrm{GO}}$ & $\mathrm{OR}(95 \% \text { C.I. })^{\mathrm{a}}$ \\
& $N$ & $N$ & $N$ & $N$ & \\
& $(\%)$ & $(\%)$ & $(\%)$ & $(\%)$ & \\
\hline 2 & 144 & 433 & 263 & 170 & \\
& $(63.4)$ & $(69.4)$ & $(66.2)$ & $(74.9)$ & \\
$<2$ & 32 & 54 & 37 & 17 & $0.45(0.24,0.84)$ \\
& $(14.5)$ & $(8.7)$ & $(9.3)$ & $(7.5)$ & \\
$>2$ & 51 & 137 & 97 & 40 & $0.66(0.42,1.06)$ \\
& $(22.5)$ & $(22.0)$ & $(24.4)$ & $(17.6)$ & \\
$P$ value $^{\mathrm{b}}$ & 0.06 & 0.14 & 0.018 & \\
\hline
\end{tabular}

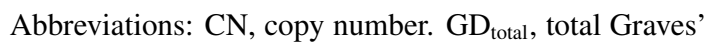
disease patients. $\mathrm{GD}_{\text {nonGO, Graves' disease patients }}$ without ophthalmopathy. $\mathrm{GD}_{\mathrm{GO}}$, Graves' disease patients with ophthalmopathy. $N(\%)$, number (percentage). OR ( $95 \%$ C.I.), odds ratio (95\% confidence interval).

a Odds ratio and $95 \%$ C.I. were estimated by applying unconditional logistic regression when compared $\mathrm{GD}_{\mathrm{GO}}$ with normal control

${ }^{b} P$ value was calculated by chi square test $(2 \times 3$ tables $)$ and was considered significant when less than 0.05 .

at reduced risk for the development of nodular hyperplasia (OR $=0.37,95 \%$ C.I.: $0.16,0.86)$ and vitiligo $(\mathrm{OR}=0.40,95 \% \mathrm{CI}: 0.21,0.78)$, but at increased risk for myxoedema $(\mathrm{OR}=2.18,95 \%$ C.I.: $1.15,4.13)$ compared with individuals with 2 copies of FCGR3B.

\section{DISCUSSION}

Several functionally relevant SNP variants are characteristic of $\mathrm{GD}$ and $\mathrm{GD}_{\mathrm{GO}}{ }^{8}$, but few studies have demonstrated an association between $\mathrm{CNV}$ and $\mathrm{GD}^{27,35,36}$. Here, we found that $\mathrm{CNV}$ in FCGR3B significantly differs between $\mathrm{GD}_{\mathrm{GO}}$ patients and healthy controls. Individuals with more or fewer than 2 copies of $F C G R 3 B$ may have reduced susceptibility to $\mathrm{GD}_{\mathrm{GO}}$. In addition, our data showed the protective effect of $F C G R 3 B \mathrm{CNV}$ on GD which was consistent with previous studies in a Caucasian population ${ }^{27}$, although the results in both studies did not reach the statistical significance. The sample size of this study did not reach $80 \%$ power for the given effect size and is a limitation. In addition, the genetic backgrounds of ethnically diverse populations should be considered. Niederer et $\mathrm{al}^{37}$ identified significant differences in FCGR3B CNV distribution among Caucasian, East Asian, and Kenyan population. Therefore, confirmation of these results by studies with larger sample sizes and in different population is warranted. More- 
Table 3 Estimated risk of several phenotypes of Graves' disease according to FCGR $3 B$ gene copy number.

\begin{tabular}{|c|c|c|c|c|c|c|c|c|c|c|c|c|}
\hline \multirow[t]{2}{*}{$\mathrm{CN}$} & \multicolumn{3}{|c|}{ Goitre } & \multicolumn{3}{|c|}{ Nodular hyperplasia } & \multicolumn{3}{|c|}{ Myxoedema } & \multicolumn{3}{|c|}{ Vitiligo } \\
\hline & $\begin{array}{c}\text { Yes } \\
N \\
(\%)\end{array}$ & $\begin{array}{c}\text { No } \\
N \\
(\%)\end{array}$ & $\begin{array}{c}\text { OR } \\
(95 \% \text { C.I. })^{b}\end{array}$ & $\begin{array}{c}\text { Yes } \\
N \\
(\%)\end{array}$ & $\begin{array}{c}\text { No } \\
N \\
(\%)\end{array}$ & $\begin{array}{c}\text { OR } \\
(95 \% \text { C.I. })^{\mathrm{b}}\end{array}$ & $\begin{array}{c}\text { Yes } \\
N \\
(\%)\end{array}$ & $\begin{array}{c}\text { No } \\
N \\
(\%)\end{array}$ & $\begin{array}{c}\text { OR } \\
(95 \% \text { C.I. })^{\mathrm{b}}\end{array}$ & $\begin{array}{c}\text { Yes } \\
N \\
(\%)\end{array}$ & $\begin{array}{c}\text { No } \\
N \\
(\%)\end{array}$ & $\begin{array}{c}\text { OR } \\
(95 \% \text { C.I. })^{\mathrm{b}}\end{array}$ \\
\hline$=2$ & $\begin{array}{c}325 \\
(68.6)\end{array}$ & $\begin{array}{c}107 \\
(72.8)\end{array}$ & 1 & $\begin{array}{c}406 \\
(70.7)\end{array}$ & $\begin{array}{c}26 \\
(53.1)\end{array}$ & 1 & $\begin{array}{c}70 \\
(61.4)\end{array}$ & $\begin{array}{c}363 \\
(71.2)\end{array}$ & 1 & $\begin{array}{c}58 \\
(59.2)\end{array}$ & $\begin{array}{c}374 \\
(71.2)\end{array}$ & 1 \\
\hline$<2$ & $\begin{array}{c}39 \\
(8.2)\end{array}$ & $\begin{array}{c}13 \\
(8.8)\end{array}$ & $\begin{array}{c}0.99 \\
(0.51,1.92)\end{array}$ & $\begin{array}{c}46 \\
(8.0)\end{array}$ & $\begin{array}{c}8 \\
(16.3)\end{array}$ & $\begin{array}{c}0.37 \\
(0.16,0.86)\end{array}$ & $\begin{array}{c}16 \\
(14.0)\end{array}$ & $\begin{array}{c}38 \\
(7.5)\end{array}$ & $\begin{array}{c}2.18 \\
(1.15,4.13)\end{array}$ & $\begin{array}{c}15 \\
(15.3)\end{array}$ & $\begin{array}{c}39 \\
(7.4)\end{array}$ & $\begin{array}{c}0.40 \\
(0.21,0.78)\end{array}$ \\
\hline$>2$ & $\begin{array}{c}110 \\
(23.2)\end{array}$ & $\begin{array}{c}27 \\
(18.4)\end{array}$ & $\begin{array}{c}1.34 \\
(0.84,2.16)\end{array}$ & $\begin{array}{c}122 \\
(21.3)\end{array}$ & $\begin{array}{c}15 \\
(30.6)\end{array}$ & $\begin{array}{c}0.52 \\
(0.27,1.02)\end{array}$ & $\begin{array}{c}28 \\
(24.6)\end{array}$ & $\begin{array}{c}109 \\
(21.4)\end{array}$ & $\begin{array}{c}1.33 \\
(0.82,2.17)\end{array}$ & $\begin{array}{c}25 \\
(25.5)\end{array}$ & $\begin{array}{c}112 \\
(21.3)\end{array}$ & $\begin{array}{c}0.70 \\
(0.42,1.16)\end{array}$ \\
\hline \multicolumn{2}{|c|}{$P$ value $^{\mathrm{a}}$} & 0.47 & & & 0.02 & & & 0.04 & & & 0.02 & \\
\hline
\end{tabular}

Abbreviations: CN, copy number; $N$ (\%), number (percentage); OR (95\% C.I.), odds ratio (95\% confidence interval).

a $P$ values were calculated by chi square test $(3 \times 2$ table $)$ and were considered significant when less than 0.05 .

${ }^{\mathrm{b}}$ Odds ratio and $95 \%$ CIs were estimated by applying unconditional logistic regression.

* Individuals with missing phenotype data were discarded from the logistic regression analysis.

over, GD patients with 2 copies of $F C G R 3 B$ are at significantly increased risk for the development of nodular hyperplasia and vitiligo, but at reduced risk for myxoedema.

$F C G R 3 B$, which is expressed by neutrophils and eosinophils, functionally links the humoural and cellular branches of the immune system and plays an important role in the activation and modulation of the immune response ${ }^{31}$. FCGR3B CNV correlates with protein expression, soluble serum Fc $\gamma$ RIIIb, neutrophil uptake of and adherence to immune complexes, and macrophage overactivity ${ }^{38}$. Dysregulation of Fc $\gamma$ RIIIb expression may contribute to the impaired clearance of immune complexes. In $\mathrm{GD} / \mathrm{GD}_{\mathrm{GO}}$, in which immune complexes may not play an important role, the relation between FCGR3B CNV, FCGR3B expression, and neutrophil activation may require further investigation.

In addition, $F C G R 3 B C N V$ could play a different role involving other co-regulatory genes, in the development of systemic and organ-specific autoimmunity. An association between low FCGR $3 B \mathrm{CNV}$ and systemic lupus erythematosus has been reported in Caucasians ${ }^{27}$. However, anti-neutrophil cytoplasmic antibody-associated systemic vasculitis, an autoimmune disease in which immune complex deposition plays only a minor role, seems to be diversely associated with $F C G R 3 B \mathrm{CN}^{27}$. Also, linkage disequilibrium between multi-allelic $F C G R 3 B \mathrm{CNV}$ and SLEassociated SNPs in the FCGR locus was defined ${ }^{37}$. However, the associations between NA1/NA2 allelic variant of $F C G R 3 B$ with GO or GD in our study were not significant ( $p$ value $>0.05$ ). Further study of the genetic interaction between $F C G R 3 B$ and other genes, such as FCGR2A, FCGR2B, and complement receptor 3 (CR3) should be considered.

In summary, this study suggests that FCGR3B $\mathrm{CNV}$ is associated with the development or progression of GD and GO, thereby providing new information on the implications of $F C G R 3 B \mathrm{CNV}$ in patients with GD.

Acknowledgements: Wen-Ling Liao and Yu-Huei Liu contributed equally to this work. We thank Hsin-Hui Chen for the technical assistance in preparation of DNA and analysing the variations. This study was supported by research grants from China Medical University, Taichung (CMU-98-asia-04 and DMR-101-118), Taiwan and 982320-B-039-008-MY3 from National Science Council, Taipei, Taiwan.

\section{REFERENCES}

1. Kraimps JL, Bouin-Pineau MH, Mathonnet M, De Calan L, Ronceray J, Visset J, Marechaud R, Barbier J (2000) Multicentre study of thyroid nodules in patients with Graves' disease. Br J Surg 87, 1111-3.

2. Gianoukakis AG, Khadavi N, Smith TJ (2008) Cytokines, Graves' disease, and thyroid-associated ophthalmopathy. Thyroid 18, 953-8.

3. Perros P, Neoh C, Dickinson J (2009) Thyroid eye disease. BMJ 338, 645-50.

4. Kuriyan AE, Phipps RP, Feldon SE (2008) The eye and thyroid disease. Curr Opin Ophthalmol 19, 499-506.

5. Khoo TK, Bahn RS (2007) Pathogenesis of Graves' ophthalmopathy: the role of autoantibodies. Thyroid 17, 1013-8.

6. Kloprogge S, Kowal L, Wall J, Frauman AG (2005) The 
clinicopathologic basis of Graves' ophthalmopathy: a review. Eur J Ophthalmol 15, 315-23.

7. Bartalena L (2005) Editorial: Glucocorticoids for Graves' ophthalmopathy: how and when. J Clin Endocrinol Metabol 90, 5497-9.

8. Bednarczuk T, Gopinath B, Ploski R, Wall JR (2007) Susceptibility genes in Graves' ophthalmopathy: searching for a needle in a haystack? Clin Endocrinol 67, 3-19.

9. Zhang F, Gu W, Hurles ME, Lupski JR (2009) Copy number variation in human health, disease, and evolution. Annu Rev Genom Hum Genet 10, 451-81.

10. Wain LV, Armour JA, Tobin MD (2009) Genomic copy number variation, human health, and disease. Lancet 374, 340-50.

11. Schaschl H, Aitman TJ, Vyse TJ (2009) Copy number variation in the human genome and its implication in autoimmunity. Clin Exp Immunol 156, 12-6.

12. Glessner JT, Wang K, Cai G, Korvatska O, Kim CE, Wood S, Zhang H, Estes A, et al (2009) Autism genome-wide copy number variation reveals ubiquitin and neuronal genes. Nature 459, 569-73.

13. Maestrini E, Pagnamenta AT, Lamb JA, Bacchelli E, SykesNH, Sousa I, Toma C, Barnby G, et al (2010) High-density SNP association study and copy number variation analysis of the AUTS1 and AUTS5 loci implicate the IMMP2L-DOCK4 gene region in autism susceptibility. Mol Psychiatr 15, 954-68.

14. Noor A, Gianakopoulos PJ, Fernandez B, Marshall CR, Szatmari P, Roberts W, Scherer SW, Vincent JB (2009) Copy number variation analysis and sequencing of the $\mathrm{X}$-linked mental retardation gene TSPAN7/TM4SF2 in patients with autism spectrum disorder. Psychiatr Genet 19, 154-5.

15. Sykes NH, Toma C, Wilson N, Volpi EV, Sousa I, Pagnamenta AT, Tancredi R, Battaglia A, et al (2009) Copy number variation and association analysis of SHANK3 as a candidate gene for autism in the IMGSAC collection. Eur J Hum Genet 17, 1347-53.

16. St Clair D (2009) Copy number variation and schizophrenia. Schizophr Bull 35, 9-12.

17. Sutrala SR, Goossens D, Williams NM, Heyrman L, Adolfsson R, Norton N, Buckland PR, Del-Favero J (2007) Gene copy number variation in schizophrenia. Schizophr Res 96, 93-9.

18. Sutrala SR, Norton N, Williams NM, Buckland PR (2008) Gene copy number variation in schizophrenia. Am J Med Genet B 147B, 606-11.

19. Tam GW, Redon R, Carter NP, Grant SG (2009) The role of DNA copy number variation in schizophrenia. Biol Psychiatr 66, 1005-12.

20. Liu W, Sun J, Li G, Zhu Y, Zhang S, Kim ST, Wiklund F, Wiley K, et al (2009) Association of a germ-line copy number variation at $2 \mathrm{p} 24.3$ and risk for aggressive prostate cancer. Canc Res 69, 2176-9.

21. Shlien A, Tabori U, Marshall CR, Pienkowska M, Feuk L, Novokmet A, Nanda S, Druker H, et al (2008)
Excessive genomic DNA copy number variation in the Li-Fraumeni cancer predisposition syndrome. Proc Natl Acad Sci USA 105, 11264-9.

22. Nielsen KV, Ejlertsen B, Moller S, Jorgensen JT, KnoopA, Knudsen H, Mouridsen HT (2008) The value of TOP2A gene copy number variation as a biomarker in breast cancer: Update of DBCG trial 89D. Acta Oncol 47, 725-34.

23. Venkatachalam R, Ligtenberg MJ, Hoogerbrugge N, Geurts van Kessel A, Kuiper RP (2008) Predisposition to colorectal cancer: exploiting copy number variation to identify novel predisposing genes and mechanisms. Cytogenet Genome Res 123, 188-94.

24. Tchatchou S, Burwinkel B (2008) Chromosome copy number variation and breast cancer risk. Cytogenet Genome Res 123, 183-7.

25. Speleman F, Kumps C, Buysse K, Poppe B, Menten B, De Preter K (2008) Copy number alterations and copy number variation in cancer: close encounters of the bad kind. Cytogenet Genome Res 123, 176-82.

26. Mamtani M, Anaya JM, He W, Ahuja SK (2010) Association of copy number variation in the FCGR3B gene with risk of autoimmune diseases. Gene Immun 11, 155-60.

27. Fanciulli M, Norsworthy PJ, Petretto E, Dong R, Harper L, Kamesh L, Heward JM, Gough SC, et al (2007) FCGR3B copy number variation is associated with susceptibility to systemic, but not organ-specific, autoimmunity. Nat Genet 39, 721-3.

28. Zhou XJ, Lv JC, Bu DF, Yu L, Yang YR, Zhao J, Cui Z, Yang R, et al (2010) Copy number variation of FCGR3A rather than FCGR3B and FCGR2B is associated with susceptibility to anti-GBM disease. Int Immunol 22, 45-51.

29. McKinney C, Fanciulli M, Merriman ME, PhippsGreen A, Alizadeh BZ, Koeleman BPC, Dalbeth N, Gow PJ, et al (2010) Association of variation in $\mathrm{Fc} \gamma$ receptor 3B gene copy number with rheumatoid arthritis in Caucasian samples. Ann Rheum Dis 69, 1711-6.

30. Marques RB, Thabet MM, White SJ, HouwingDuistermaat JJ, Bakker AM, Hendriks GJ, Zhernakova A, Huizinga TW, et al(2010) Genetic variation of the Fc gamma receptor $3 \mathrm{~B}$ gene and association with rheumatoid arthritis. PLoS ONE 5, e13173.

31. Li X, Ptacek TS, Brown EE, Edberg JC (2009) Fc $\gamma$ receptors: structure, function and role as genetic risk factors in SLEFc $\gamma$ R and SLE. Gene Immun 10, 380-9.

32. Liao WL, Chen RH, Lin HJ, Liu YH, Chen WC, Tsai Y, Wan L, Tsai FJ (2011) The association between polymorphisms of B7 molecules (CD80 and CD86) and Graves' ophthalmopathy in a Taiwanese population. Ophthalmology 118, 553-7.

33. Field SF, Howson JM, Maier LM, Walker S, Walker NM, Smyth DJ, Armour JA, Clayton DG, et al (2009) Experimental aspects of copy number variant assays at CCL3L1. Nat Med 15, 1115-7.

34. Livak KJ, Schmittgen TD (2001) Analysis of relative 
gene expression data using real-time quantitative PCR and the $2^{-\Delta \Delta C_{\mathrm{T}}}$ method. Methods 25, 402-8.

35. Lv J, Yang Y, Zhou X, Yu L, Li R, Hou P, Zhang $\mathrm{H}$ (2010) FCGR3B copy number variation is not associated with lupus nephritis in a Chinese population. Lupus 19, 158-61.

36. Huber AK, Concepcion ES, Gandhi A, Menconi F, Smith EP, Keddache M, Tomer Y (2011) Analysis of immune regulatory genes' copy number variants in Graves' disease. Thyroid 21, 69-74.

37. Niederer HA, Willcocks LC, Rayner TF, Yang W, Lau YL, Williams TN, Scott JA, Urban BC, et al (2010) Copy number, linkage disequilibrium and disease association in the FCGR locus. Hum Mol Genet 19, 3282-94.

38. Willcocks LC, Lyons PA, Clatworthy MR, Robinson JI, Yang W, Newland SA, Plagnol V, McGovern NN, et al (2008) Copy number of FCGR3B, which is associated with systemic lupus erythematosus, correlates with protein expression and immune complex uptake. $J$ Exp Med 205, 1573-82. 